(7)

\title{
Asymmetric Dynamics of Oil Price and Environmental Degradation: Evidence from Pakistan
}

\author{
${ }^{a}$ Imran Sharif Chaudhry, ${ }^{b}$ Mohamed Azali, ${ }^{b}$ Muhammad Faheem, ${ }^{b}$ Sajid Ali \\ ${ }^{a}$ Director, School of Economics, Bahauddin Zakariya University, Multan, Pakistan, Email: imran@bzu.edu.pk \\ ${ }^{\mathrm{b}}$ Faculty of Economics and Management, Universiti Putra, Malaysia
}

\begin{tabular}{l} 
ARTICLE DETAILS \\
\hline History: \\
Accepted 15 March 2020 \\
Available Online 31 March 2020
\end{tabular}

Keywords:

Oil price, NARDL, Environmental

Degradation, $\mathrm{CO} 2$ emissions,

Energy Consumption

JEL Classification:

K32, P18, Q56

DOI: $10.47067 /$ reads.v6i1.179

\begin{abstract}
The main objective of the study is to explore asymmetric impact of oil price on environmental degradation in Pakistan over the period 19752018. The study employs the nonlinear autoregressive distributive lag (NARDL) method to check the asymmetric connection of oil price with carbon dioxide (CO2) emissions which represents environmental degradation along with gross capital formation, energy consumption, foreign direct investment and population. The NARDL result expresses that there is different effect of oil price as we break it into positive and negative changes, and decrease in oil price has a greater effect on environmental degradation in Pakistan. The other variables, FDI and energy consumption and population, have a positive and significant effect on $\mathrm{CO} 2$ emission. The study provides the policies for policymakers and government officials after uncovering the asymmetric relationship between oil and other variables with an environment that would be helpful in policymaking for Pakistan.
\end{abstract}

(C) 2020 The authors. Published by SPCRD Global Publishing. This is an open access article under the Creative Commons Attribution-

NonCommercial 4.0

Corresponding author's email address: imran@bzu.edu.pk

\section{Introduction}

Environmental degradation is a global problem in which $\mathrm{CO}_{2}$ emissions are a significant cause of the increasing global temperature (Stocker, 2014; Usman et al., 2020). The significance of environmental degradation accepted globally at the global conference in Brazil in 1992 (UN, 1992) and obtaining importance in 2016 when all countries shave ratified the Paris Agreement policy guidelines of the United Nations Organization's Framework for the mitigation of Greenhouse-Gases. While most countries are struggling to curtail the effects of environmental degradation, a meaningful change needs a large amount of money and funding, which is not possible in most underdeveloped economies. In underdeveloped countries, the FDI pattern appears to be pollution heaven because these countries offer low wage labor, cheap resources, and lax regulations about the environment (Kathuria, 2016; Sarkodie \& Strezov, 2019). The theory behind determining the effect of oil prices on environmental quality is that oil prices will decide the consumption of fossil fuel that contributes 40 percent of the world's $\mathrm{CO}_{2}$ emissions. Higher oil prices can indirectly affect carbon dioxide emissions through a reduction in 
energy consumption. From the other side, energy consumption increases due to a reduction in oil price. The price of oil, therefore, acts as an indicator of variations in environmental quality and its effect is different on environment (Boufateh, 2019; Malik et al., 2020).

The connection between FDI and the environmental degradation is seen primarily by pollution haven hypothesis which states that rich countries apply tight environmental regulations, while underdeveloped economies have lax environment related laws that attracts polluted or dirty industries (Levinson 1996, Cole \& Elliott 2005, Hassaballa 2014; Guzel \& Okumus, 2020; Nadeem et al., 2020). This trend is a cause of the rise of specialization in dirty industries in underdeveloped countries and clean industries in developed economies. The association between environmental degradation and foreign direct investment is, therefore, positive. On the other side, according to pollution halo hypothesis or neo-technology school of thought, the correlation between direct foreign investments and quality of the environment is positive through information spillovers and up-gradation of technology (De Mello, 1999) through a shift of environmentally sound technology from rich countries to underdeveloped economies (Gorg and Stebb). Hence, in underdeveloped economies, the association between FDI and environmental degradation is negative (Lee, 2013). The key reason why $\mathrm{CO}_{2}$ emissions are growing is the rapid rise in industrial sector energy demand due to globalization. The average annual energy usage also rises by 13.5 percent (Pakistan Economic Survey 2017). Gas, energy, coal, and crude oil consumption have increased by 9.6 percent, 7.3 percent, 4.9 percent, and 7.4 percent, respectively (Pakistan Economic Survey 2017). The usage of all these items degrades the environment in Pakistan.

The increased population levels and consequent demand for energy, food, and housing have changed land-use practices significantly and depleted Pakistan's forests considerably in relation to the environment. Poverty is one of the consequences of population growth, and its lifestyle is a significant factor in depleting the environment, either by the demand for fuel for cooking food or by its survival requirements. Limited opportunities for people and unfair distribution of resources cause pull and push factors for the people who live below the poverty line and are exploiting multiples to overburden population density and the environment (Mehmood and Chaudhary, 2012; Khan et al. 2016). Moreover, the previous literature uses different econometric methods to show the association of different macroeconomic variables including oil price and environment (Sarwar et al., 2013; Ali et al., 2014; Faheem et al., 2014; Aftab et al., 2015; Anwar et al., 2016; Ali \& Nazar, 2017; Boufateh, 2019; Faheem et al., 2019; Khan \& Chaudhry; 2019; Safdar et al., 2019; Anser et al., 2020; Iram et al., 2020; Ali et al., 2020; Faheem et al., 2020; Malik et al., 2020).

The GDP of Pakistan grew by 375 percent from 1980 to 2017, while CO2 emission has been enhanced by just 118 percent (World Bank, 2018). Although Pakistan contributes only less than 1 percent in total global $\mathrm{CO} 2$ emissions, Pakistan is still in the top five nations, which are seriously affected by environmental degradation according to the Global Climate Risk Index of 2017 (Sharif et al. 2017). According to the climate change report by the Asian Development Bank (ADB), in Pakistan, the average temperature has grown by 0.5 centigrade in the past 50 years, while the days with heat wave per year have risen by six times. These environmental changes have many social and economic impacts such as a drop in crop yields, increased variations in river water, higher rate of evaporation, drought, increased mortality due to extreme heat waves, and a significant threat to the generation of hydropower (Sharif and Raza, 2016). Environmental degradation has now become a problem of national security (Sharif et al., 2017), where the alleviation of its impact requires Pakistan to upgrade its infrastructure for transport, irrigation, and electricity. According to the Paris Agreement of United Nations framework, the government decides to mitigate 20 percent of GHG emissions by 2030, which 
will cost about USD 45000 million for Pakistan.

Pakistan, however, is self-sustaining in natural gas. Still, its consumption of oil depends heavily on imports of petroleum products and other petroleum-related products, which are Pakistan's most important imports (Sharif and Raza, 2016). Pakistan has been faced with an annual energy deficit of 4000-5000 megawatts since the 200os, initiating daily load shedding of 8 to 10 hours in various rural and urban areas (Rafique and Rehman, 2017). Thus, to tackle this energy deficit, Pakistan has been bought energy from rental power plants, which produces 40 percent of total electricity in 2017 (NTDC, 2017). Moreover, Pakistan generates 21 percent electricity from crude oil (World Bank, 2018), and it enhances the financial strain on the government (Kamran, 2018). Although Pakistan is also facing the highest distribution and transmission losses of 23 percent annually and losses in electricity bill collection of 12 percent per annual (NTDC, 2017), making power (energy) more expensive day by day (Rafique and Rehman, 2017).

Based on the above debate, this study attempts to find if there is any asymmetric impact of oil price on $\mathrm{CO} 2$ emission/environmental degradation exists or not. First, we are using oil prices along with other macroeconomic variables, which is a new contribution for Pakistan. Second, we perform analysis by using NARDL approach to analyze asymmetric relationships between the variables, as to how oil price increases or decreases effects environmental degradation in Pakistan. The remainder of the paper structured as follows. Section 2 is reserved for literature review. Section 3 deals with development of model and methodology. Section 4 gives results discussion and last section provides conclusion.

\section{Literature Review}

In mostly previous literature, the association among energy use, GDP growth and environmental degradation has been discussed (Huang et al., 2008; Ozturk, 2010; Saboari and Sulaiman, 2013; Bilgili et al. 2017). However, a minimal number of studies are found which concentrate on the association between oil prices/oil consumption with environmental degradation (Maji et al. 2017). Due to this fact, we are giving the brief review of the studies which have examined the effect of oil prices on carbon dioxide emissions/environmental degradation. De bruyn et al. (1998) analyzed the impact of oil prices and GDP on environmental degradation in the Great Britain, Holand, Germany, and the United States of America for the year 1965-1995. The findings showed that the rise in US oil prices hurt environmental degradation. For the other nations, there was no significant correlation between oil price and environmental degradation was found. Lindmark (2002) looked at the relationship between fuel prices, technology, GDP, and CO2 emissions in Sweden. The outcomes confirmed that fuel price increase had a reducing impact on pollution. He and Richard (2010) examined the effect manufacturing sector, GDP and trade openness on oil price in Canada for the year 1949-2006. The findings confirmed that the rise in gasoline price mitigated CO2 emissions. For the years between 1949 and 2009, Payne (2012) analyzed the impact of oil prices on environment in the United States and found a negative impact of oil prices on the environment. Hammoudeh et al. (2014); Zhang and Zhang (2016); Wang and Li (2016) and McCollum et al. (2016) illustrated the mitigating impact of $\mathrm{CO}_{2}$ emissions by achieving similar outcomes by increasing oil prices. In similar with these studies Boufateh (2019) and Malik et al. (2020) shows the nonlinear effect of oil price on environment.

Contrary to expectations, some empirical studies showed that an enhancement (decline) in oil price has a positive (negative) impact on environmental degradation, whereas other studies showed that there was no substantial correlation between the price of oil and environmental degradation. Sadorsky (2009) analyzed the effect of oil price, renewable energy, and GDP on carbon dioxide 
emissions in the G-7 economies for the panel data from 1981 to 2006 . The outcomes indicated that the consumption of renewable energy and GDP were main cause of enhancing $\mathrm{CO}_{2}$ emissions. Salim and Rafiq (2012) addressed the association between oil price, renewable energy and carbon dioxide emissions in underdeveloped economies for the year 1980-2007. The results suggested that oil price had no substantial effect on carbon dioxide emissions and renewable energy. The association between oil price and the value of carbon dioxide allowance in China was examined by Zhang and Zhang (2016) for the year 2010-2015 and indicated that oil price had a favorable effect on the value of carbon dioxide allowance. Nwani (2017), in his ARDL model, estimated the effect of oil prices and energy consumption on greenhouse gases in Ecuador for the year 1970-2014 and indicated that rising oil prices had a growing impact on pollution. In another study, Blazquez et al. (2017) examined the effect of shocks in oil price on environmental degradation in Spain for the year 1970 to 2015 and found that shocks in oil price had no major influence on environment.

The links between the energy use/consumption and environmental degradation have been explored by Huang et al. (2008), Pao and Tsai (2010), Saboari and Sulaiman (2013) Lee and Chang (2007) and Presno et al. (2017). Haseeb et al. (2017) explored the association between energy consumption, population and pollution in BRICS countries and found a positive relationship of energy consumption and population with the level of pollution. Pao and Tsai (2010) observed the impact of energy usage and GDP on environmental degradation in BRICS economies and observed that energy usage and GDP caused environmental degradation. Saboori and Sulaiman (2013) analyzed the environmental degradation effects of energy use and GDP growth from 1981 to 2010 and found that the environment is adversely affected by the GDP growth of the Malaysian economy and energy use. Zeng and Eastin (2012) noted that FDI helped to improve the host country's environmental quality through preventive measures by FDI receiving companies, which also led to increasing preventive actions by non-FDI companies under competitive circumstances. On the other hand, Le and Attaullah (2002), Suleman (2009), Zaman et al. (2012), Raza et al. (2012), Najia et al. (2013) and Iqbal et al. (2014) examined the effect of FDI on pollution and found a direct linkage between FDI and pollution in Pakistan. According to them, the economy of Pakistan will not be competitive unless the proper set-up of the development of human resources, the increase in indigenous investments, institutional, entrepreneurship, cultural, socio-economic change.

\section{Methodology}

The data for this study is taken from different sources. The proxy used for the environmental degradation is carbon dioxide ( $\mathrm{CO}_{2}$ ) emissions, and for the oil price, crude oil price per barrel of brent is used. The data is sourced from BP Statistical Review. The other variables, like a foreign direct investment (FDI), total population, energy consumption and gross capital formation (GCF) is taken from the World Development Indicators (WDI). The data span covers from the year 1975-2018 for Pakistan and all variables are taken in logarithmic form.

The literature shows the association of oil price with environmental quality through different techniques of cointegration, Granger causality and ARDL method, GMM, PMG, quantile regression to show short-run and long-run symmetrically in time series analysis and panel analysis. The study uses the nonlinear ARDL, which is recently presented by Shin, Yu, and Greenwood-Nimmo (2014), setting with the extension of ARDL to achieve the study objective that is asymmetric affect oil price on environmental degradation. This methodology have several advantages such as; Firstly, it is free from the restriction of order of integration as it may be employed if variable are I(1) or mixture I(O) and I(1) order of integration rather than any variable is in I(2) order of integration. Secondly, it simultaneously shows short-term and long-term components, which eliminates serial correlation in data and 
endogeneity of variables (Pesaran and Shin, 1999). Thirdly, it is appropriate to use this method even when we have small size of sample (Pesaran et al. 2001).

On the behalf of theoretical background following are determinants of environment,

$$
C \mathrm{O}_{2 t}=f(O P, G C F, F D I, E C, P O P)
$$

This methodology uses the following specification to achieve our objective:

$$
C O_{2 t}=\alpha_{0}+\alpha_{1} O P_{t}+\alpha_{2} G C F_{t}+\alpha_{3} F D I_{t}+\alpha_{4} E C_{t}+\alpha_{5} P O P_{t}+\mu_{t}
$$

Where $\mathrm{CO} 2$, OP, GCF, FDI, EC and POP show CO2 emission, oil price, gross capital formation, foreign direct investment, energy consumption and population, respectively. Moreover, $\alpha=(\alpha 0, \alpha 1, \alpha 2$, $\alpha_{3}, \alpha_{4}$ and $\alpha_{5}$ ) indicates a vector to estimate the long-run parameters.

To estimate the above model, first, this study applies the ARDL bounds formulation by using the following specified model:

$$
\begin{aligned}
& \Delta C O_{2 t}=\alpha_{0}+\sum_{i=1}^{l} a_{1 i} \Delta C O_{2 t-1}+\sum_{i=0}^{p} \alpha_{2 i} \Delta O P_{t-i}+\sum_{i=0}^{q} \alpha_{3 i} \Delta G C F_{t-i}+\sum_{i=0}^{r} \alpha_{4 i} \Delta F D I_{t-i}+\sum_{i=0}^{s} \alpha_{5 i} \Delta E C_{t-i}+\sum_{i=0}^{t} P O P_{t-i} \\
& +\beta_{1} C O_{2 t-1}+\beta_{2} O P_{t-1}+\beta_{3} G C F_{t-1}+\beta_{4} F D I_{t-1}+\beta_{5} E C_{t-1}+\beta_{6} P O P_{t-1}+\mu_{t}
\end{aligned}
$$

In the above equation, $\Delta$ shows the first difference operator of the concerned variable and the deterministic drift parameter is ao. From the above equations, we estimate the unrestricted error correction model (ECM) as follows:

$$
\begin{aligned}
& \Delta C O_{2 t}=\alpha_{0}+\sum_{i=1}^{l} a_{1} \Delta C O_{2}+\sum_{t-i}^{p} \alpha_{2} \Delta O P_{t-i}+\sum_{i=0}^{q} \alpha_{3} \Delta G C F_{t-i}+\sum_{i=0}^{r} \alpha_{4} \Delta F D I_{t-i}+\sum_{i=0}^{s} \alpha_{5} \Delta E C_{t-i}+\sum \alpha_{6} \Delta P O P_{t-i} \\
& +\lambda E C T-1+v t_{t}
\end{aligned}
$$

In the above equation, $\lambda$ indicates a parameter for the speed of adjustment and ECT implies the residuals of the estimated model. The formulation of asymmetric behaviour of oil price in agreement with the nonlinear ARDL model where oil price decomposes into positive and negative parts is:

$$
\mathrm{CO}_{2 t}=\beta_{1}+\beta_{2}^{+} \mathrm{OP}^{+}{ }_{t}+\beta_{2}^{-} O P_{t}^{-}+\beta_{3} X_{t}+\mu_{t}
$$

Based on the nonlinear model (Equation (5)), $\beta 2+$ shows oil price increase effect on carbon dioxide emission in long-run in the equation (6), which is expected to be negative. And $\beta 2$ - in equation (7) shows the oil price decrease effect.

$$
\begin{aligned}
& \beta_{2}^{+} O P_{t}^{+}=\sum_{j=1}^{t} \Delta L O P_{j}^{+}=\sum_{j=1}^{t} \max \left(\Delta O P_{j}, 0\right) \\
& \beta_{2}^{-} O P_{t}^{-}=\sum_{j=1}^{t} \Delta O P_{j}^{-}=\sum_{j=1}^{t} \max \left(\Delta O P_{j}, 0\right)
\end{aligned}
$$

Shin, Yu, and Greenwood-Nimmo (2014) introduced NARDL setting with the extension of ARDL 
as:

$$
\begin{aligned}
& \Delta C O_{2 t}=\alpha_{0}+\sum_{i=1}^{l} a_{1 i} \Delta C O_{2 t-1}+\sum_{i=0}^{p 1} \alpha^{+}{ }_{2 i} \Delta O P^{+}{ }_{t-i}+\sum_{i=0}^{p 2} \alpha^{-}{ }_{2 i} \Delta O P^{-}{ }_{t-i}+\sum_{i=0}^{q} \alpha_{3 i} \Delta G C F_{t-i}+\sum_{i=0}^{r} \alpha_{4 i} \Delta F D I_{t-i}+\sum_{i=0}^{s} \alpha_{5 i} \Delta E C_{t-i}+\sum_{i=0}^{t} \alpha_{6 i} \Delta P O P_{t-i} \\
& +\beta_{1} C O_{2 t-1}+\beta_{2}^{+} O P_{t-1}^{+}+\beta^{-}{ }_{2} O P^{-}{ }_{t-1}+\beta_{3} G C F_{t-1}+\beta_{4} F D I_{t-1}+\beta_{5} E C_{t-1}+\beta_{6} P O P_{t-1}+\mu_{t}
\end{aligned}
$$

The following hypothesis is used to measure long run and short run asymmetry by $\beta 2+$ and $\beta 2$ - , $\alpha 2+$ and $\alpha 2-$, respectively:

$$
\begin{gathered}
\text { Ho: } \beta 2+=\beta 2-=0 \\
H_{0}: \sum_{i=0}^{p 1} \alpha^{+}{ }_{2 i}=\sum_{i=0}^{p 2} \alpha^{-}{ }_{2 i}
\end{gathered}
$$

for all $i=0, \ldots ., p$

\section{Results and Discussion}

The result of the ADF and Phillips Perron test confirms that $\mathrm{CO} 2$ emission, oil price, gross capital

\begin{tabular}{|c|c|c|c|c|}
\hline \multicolumn{3}{|c|}{ Level } & \multicolumn{2}{|c|}{ First Difference } \\
\hline Variable & $\mathrm{ADF}$ & P & $\mathrm{ADF}$ & \\
\hline $\mathrm{CO} 2$ & 1.41 & 2.55 & $-3 \cdot 36 * *$ & $-3 \cdot 36 * *$ \\
\hline $\mathrm{OP}$ & -1.40 & -1.49 & $-5.61^{* * *}$ & $-5 \cdot 56^{* * *}$ \\
\hline GCF & -2.09 & -2.21 & $-6.21 * * *$ & $-6.18 * * *$ \\
\hline FDI & -2.89 & -1.91 & $-4.79^{* * *}$ & $-4 \cdot 77^{* * *}$ \\
\hline $\mathrm{EC}$ & 0.41 & -1.18 & $-10.52^{* * *}$ & $-9 \cdot 31^{* * *}$ \\
\hline POP & 1.86 & 8.09 & $-3.01 * *$ & $-2.09^{* *}$ \\
\hline
\end{tabular}
formation, FDI, energy consumption and population are non-stationary at the level and stationary when converted to the first difference, representing that the variables are I(1).

Table 1 ADF and PP Unit Root tests

Note: ${ }^{* * *},{ }^{* *}$ express significant at $1 \%$ and $5 \%$.

The next step is to perform a cointegration test for linear and nonlinear specification and results clearly show the cointegration only in case of the nonlinear specification. The computed F-statistic is shown in the following table 2.

Table 2 ARDL Bound Test for Cointegration

\begin{tabular}{|l|l|l|l|l|}
\hline & F-Statistic & $\begin{array}{l}\text { Lower } \\
\text { Bound 95\% }\end{array}$ & $\begin{array}{l}\text { Upper } \\
\text { Bound95\% }\end{array}$ & Decision \\
\hline Linear ARDL & 1.7953 & 2.62 & 3.79 & No-Cointegration \\
\hline Asymmetric ARDL & 8.24 & 2.45 & 3.61 & Cointegration \\
\hline
\end{tabular}

The results of diagnostic tests and long-run estimations are given in table 3. The diagnostics outcomes show model is cleared from autocorrelation, heteroskedasticity problem and structurally stable and free from normality issue. Furthermore, CUSUM and CUSUM of squares test results are presented in the following figures that test the stability of the model. Moreover, the overall scenario of our variables and their correlation is given in the table (see appendix).

The long-run results show the different effects of positive changes and negative changes of oil price on $\mathrm{CO}_{2}$ emission. In simple, results reveal that a 1 percent increase in oil price is associated to 
0.042 percent decrease in $\mathrm{CO} 2$ emission in the long run. The results also show that 1 percent decrease in oil price is associated to a 0.097 percent increase in $\mathrm{CO}_{2}$ emission in the long-run. The other variables, FDI and EC and population, have a positive effect on $\mathrm{CO} 2$ emission in the long run while GCF is insignificant. The findings are in agreement with the literature conducted in different regions i.e. De bruyn et al. (1998), He and Richard (2010), Lindmark (2002), Hammoudeh et al. (2014), Zhang and Zhang (2016); Wang and Li (2016); Boufateh (2019); Malik et al., (2020).

Table 3 ARDL Long- Run Estimation and Diagnostic Checks

\begin{tabular}{|l|l|l|l|}
\hline Regressors & Coefficients & Standard error & t-ratio (Prob.) \\
\hline OP+ & -0.042 & 0.014 & $-3.035^{* * *}(0.004)$ \\
\hline OP- & -0.097 & 0.029 & $-3.253^{* * *}(0.002)$ \\
\hline GCF & 0.031 & 0.104 & $0.295(0.769)$ \\
\hline FDI & 0.008 & 0.004 & $1.815^{*}(0.078)$ \\
\hline EC & 1.013 & 0.142 & $7.121^{* * *}(0.000)$ \\
\hline POP & 0.824 & 0.245 & $3.368^{* * *}(0.001)$ \\
\hline Intercept & -5.915 & 1.902 & $-3.109^{* * *}(0.003)$ \\
\hline R Square & 0.999 & Serial Correlation & $0.485(0.619)$ \\
\hline DW Stat & 2.016 & Functional Form & $0.937(0.340)$ \\
\hline Normality & $2.036(0.361)$ & Heteroscedasticity & $0.284(0.956)$ \\
\hline WLR & $6.432(0.001)$ & WSR & $4.327(0.005)$ \\
\hline
\end{tabular}

Note: ${ }^{* *}, * *, *$ shows significance level at $1 \%, 5 \%$ and $10 \%$. the values in ( ) are p-values.

The short-run results show the negative oil price changes have more effect than positive oil price changes on $\mathrm{CO}_{2}$ emission, showing that 1 percent decrease in oil price with a 0.051 percent increase in $\mathrm{CO} 2$ emission in the short-run. And 1 percent raise in oil price associated with 0.022 percent decrease in carbon dioxide emission in the short-run. The remaining variables, FDI, EC and population, have a positive association with carbon dioxide emission in the short-run while GCF is found insignificant.

Table 4 ARDL Short -Run Coefficients

\begin{tabular}{|l|l|l|l|}
\hline Regressors & Coefficients & Standard error & t-ratio [prob.] \\
\hline $\mathrm{D}(\mathrm{OP}+)$ & -0.022 & 0.008 & $-2.659^{* *}(0.011)$ \\
\hline $\mathrm{D}(\mathrm{OP}-)$ & -0.051 & 0.014 & $-3.702^{* * *}(0.000)$ \\
\hline $\mathrm{D}(\mathrm{GCF})$ & 0.016 & 0.054 & $0.294(0.771)$ \\
\hline $\mathrm{D}(\mathrm{FDI})$ & 0.004 & 0.002 & $1.846^{*}(0.073)$ \\
\hline $\mathrm{D}(\mathrm{EC})$ & 0.531 & 0.079 & $6.711^{* * *}(0.000)$ \\
\hline $\mathrm{D}(\mathrm{POP})$ & 0.432 & 0.158 & $2.738^{* * *}(0.009)$ \\
\hline ECT & -0.524 & 0.059 & $-8.865(0.000)$ \\
\hline
\end{tabular}

Note: ${ }^{*}, * *, * * *$ shows significance level at $10 \%, 5 \%$ and $1 \%$ respectively.

Figure 1 CUSUM Test 


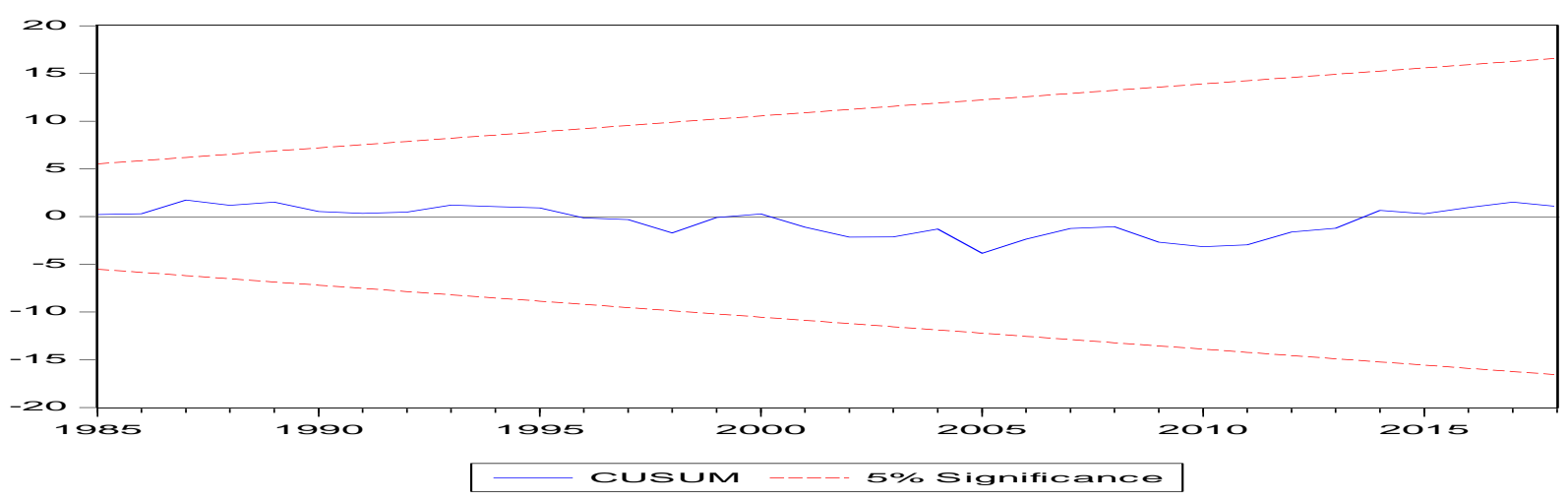

Figure 2 CUSUM of Square Test

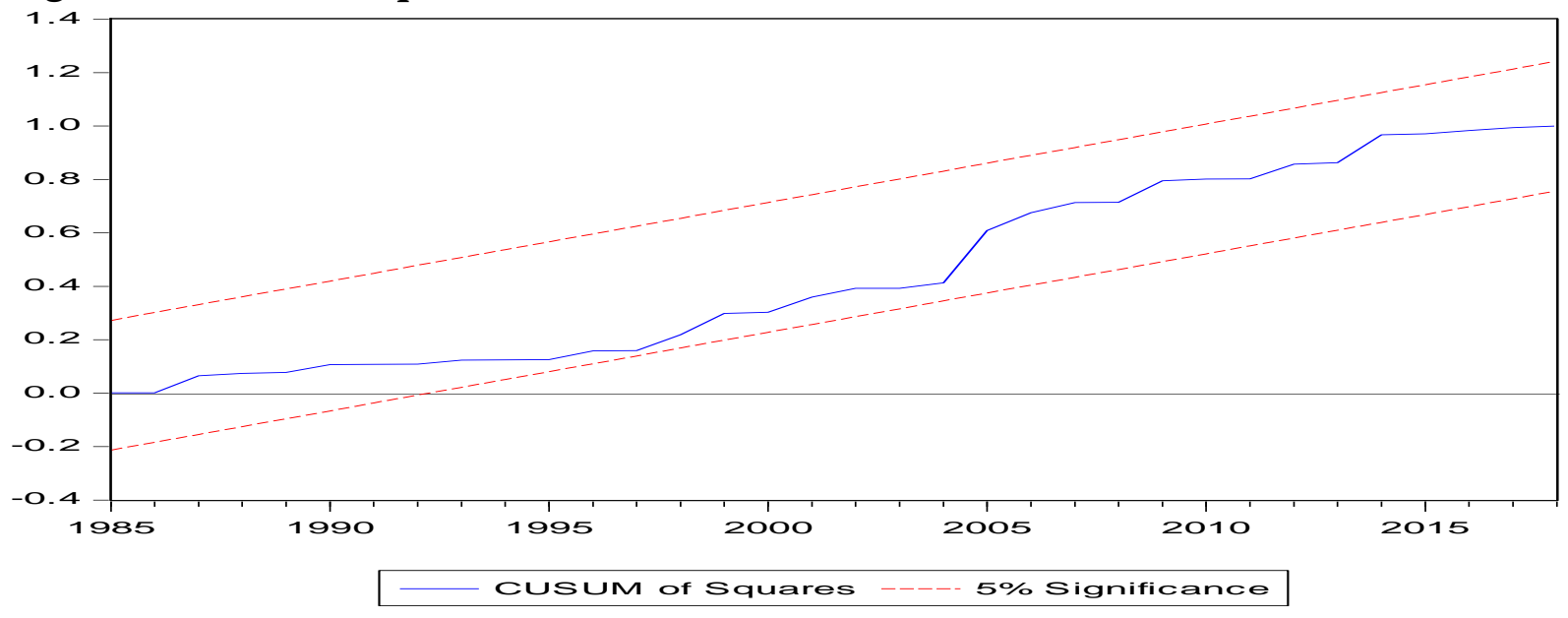

The study applied Wald test to check the asymmetric relation of oil price and $\mathrm{CO}_{2}$ emission, and results are presented in the above table 3 that are in favour of the long run and short run asymmetry. Moreover, the graphical representation of asymmetry is explained by following a cumulative dynamic multiplier graph.

\section{Figure 3 Dynamic Multiplier Graph}

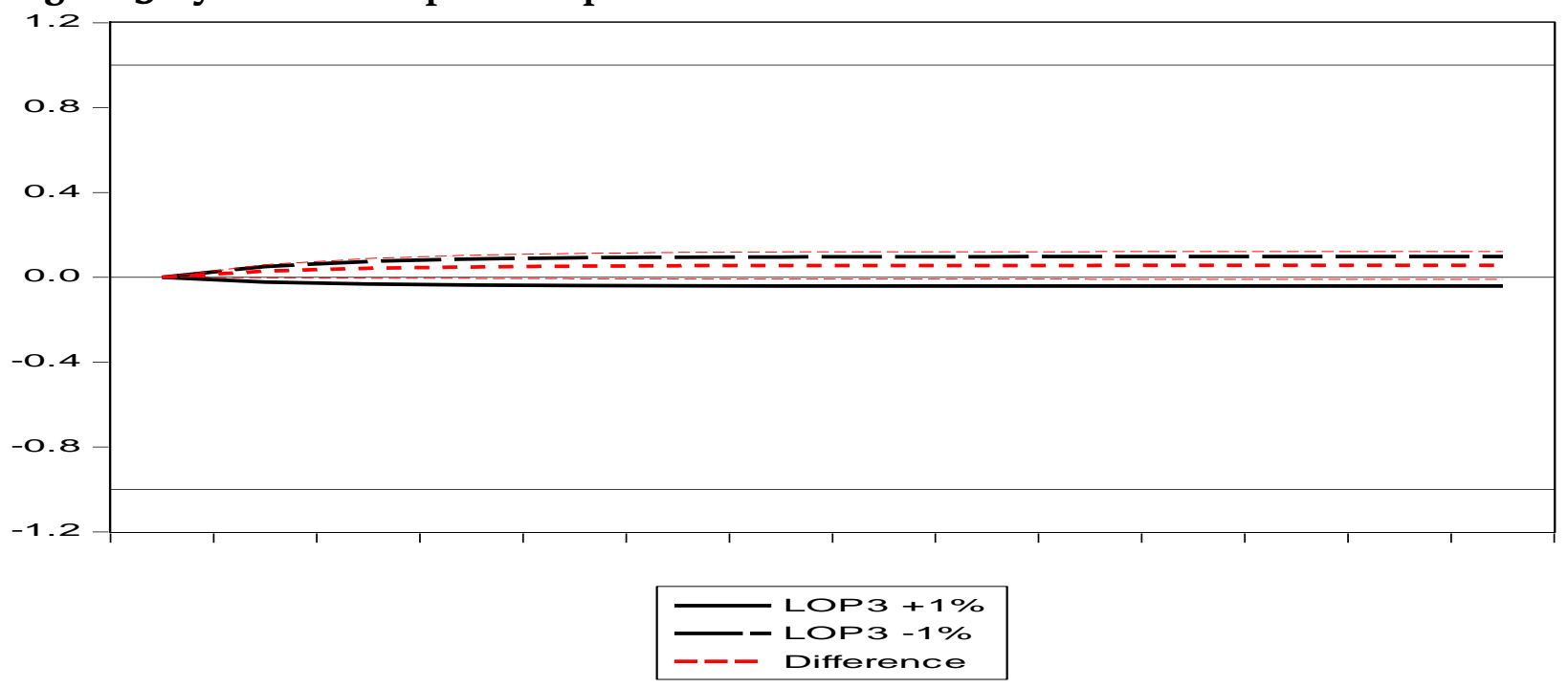




\section{Conclusion}

The study scrutinizes the impact of oil price on environmental degradation in Pakistan for the year 1975-2018. The study uses NARDL model to achieve the objective. The NARDL result expresses that oil price has a different effect as we break into positive and negative changes, and oil price decrease has a more severe impact on environmental degradation in Pakistan. The other variables, FDI, energy consumption and population have a significant and positive association with $\mathrm{CO}_{2}$ emissions in the short-run while gross capital formation is found insignificant. On behalf of findings, the study provides the policies for policymakers and government officials after uncovering the asymmetric relationship between oil and other variables with an environment that would be helpful in policymaking for Pakistan.

\section{References}

Aftab, M. R., Rehman, M., Abdul, C., \& Faheem, M. (2015). Food Prices and its Impact on Poverty in Pakistan. Pakistan Journal of Social Sciences (PJSS), 35(2).

Albornoz, F., Cole, M. A., Elliott, R. J., \& Ercolani, M. G. (2009). In search of environmental spillovers. World Economy, 32(1), 136-163.

Ali, S., Faheem, M., \& Fakher, A. (2014). Role of information technology (IT) in business management: an overview. International Journal of Management, IT and Engineering, 4(9), 48-56.

Ali, S., \& Nazar, R. (2017). Impact of Foreign Capital Inflows and Money Supply on Exchange Rate: A Case Study of Pakistan. Review of Economics and Development Studies, 3(1), 83-90.

Ali, S., Yusop, Z., Kaliappan, S. R., \& Chin, L. (2020). Dynamic common correlated effects of trade openness, FDI, and institutional performance on environmental quality: evidence from OIC countries. Environmental Science and Pollution Research, 1-12.

Anser, M. K., Abbas, Q., Chaudhry, I. S., \& Khan, A. (2020). Optimal oil stockpiling, peak oil, and general equilibrium: case study of South Asia (oil importers) and Middle East (oil supplier). Environmental Science and Pollution Research, 1-10.

Anwar, Y., Farooq, F., Ullah, S., \& Faheem, M. (2016). Impact of Financial Globalization on Human Capital: Evidence from Pakistan. Pakistan Journal of Social Sciences (PJSS), 36(2).

Bilgili, F., Koçak, E., Bulut, Ü., \& Sualp, M. N. (2016). How did the US economy react to shale gas production revolution? An advanced time series approach. Energy, 116, 963-977.

Blazquez, J., Martin-Moreno, J. M., Perez, R., \& Ruiz, J. (2017). Fossil fuel price shocks and CO2 emissions: the case of Spain. The Energy Journal, 38(6).

Boufateh, T. (2019). The environmental Kuznets curve by considering asymmetric oil price shocks: evidence from the top two. Environmental Science and Pollution Research, 26(1), 706-720.

Cole, M. A., \& Elliott, R. J. (2005). FDI and the capital intensity of "dirty" sectors: a missing piece of the pollution haven puzzle. Review of Development Economics, 9(4), 530-548.

De Bruyn, S. M., van den Bergh, J. C., \& Opschoor, J. B. (1998). Economic growth and emissions: reconsidering the empirical basis of environmental Kuznets curves. Ecological Economics, 25(2), 161-175.

De Mello, L. R. (1999). Foreign direct investment-led growth: evidence from time series and panel data. Oxford economic papers, 51(1), 133-151.

Faheem, M., Fakher, A., \& Ali, S. (2014). Inequality and Economic Growth: An Overview. International Journal of Physical and Social Sciences, 4(9), 159-169.

Faheem, M., Mohamed, A., Farooq, F., \& Ali, S. (2019). Do Migrant Remittances Spur Financial Development in Pakistan? evidence From Linear and Nonlinear Ardl Approach. Review of Economics and Development Studies, 5(4), 869-880.

Faheem, M., Azali, M., Chin, L., \& Mazlan, N. S. (2020). New Evidence of Oil Price Fluctuations and 
Manufacturing Output in Saudi Arabia, Kuwait and United Arab Emirates. Pakistan Journal of Commerce and Social Sciences (PJCSS), 14(1), 300-333.

Guzel, A. E., \& Okumus, İ. (2020). Revisiting the pollution haven hypothesis in ASEAN-5 countries: new insights from panel data analysis. Environmental Science and Pollution Research, 1-11.

Görg, H., \& Strobl, E. (2005). Spillovers from foreign firms through worker mobility: An empirical investigation. Scandinavian Journal of Economics, 107(4), 693-709.

Hammoudeh, S., Nguyen, D. K., \& Sousa, R. M. (2014). Energy prices and CO2 emission allowance prices: A quantile regression approach. Energy Policy, 70, 201-206.

Haseeb, A., Xia, E., Baloch, M. A., \& Abbas, K. (2017). Financial development, globalization, and CO 2 emission in the presence of EKC: evidence from BRICS countries. Environmental Science and Pollution Research, 25(31), 31283-31296.

Hassaballa, H. (2014). The effect of lax environmental laws on foreign direct investment inflows in developing countries. Journal of Emerging Trends in Economics and Management Sciences, 5(3), 305-315.

He, J., \& Richard, P. (2010). Environmental Kuznets curve for $\mathrm{CO}_{2}$ in Canada. Ecological Economics, 69(5), 1083-1093.

Huang, B. N., Hwang, M. J., \& Yang, C. W. (2008). Does more energy consumption bolster economic growth? An application of the nonlinear threshold regression model. Energy Policy, 36(2), 755767.

Iqbal, N., Ahmad, N.,Haider, Z., \& Sonia, A. (2014). Impact of Foreign Direct Investment (FDI) on GDP: A Case Study from Pakistan. International Letters of Social and Humanities Sciences, 16, 73-80.

Iram, R., Anser, M. K., Awan, R. U., Ali, A., Abbas, Q., \& Chaudhry, I. S. (2020). Prioritization of Renewable Solar Energy To Prevent Energy Insecurity: An Integrated Role. The Singapore Economic Review.

Kathuria, V. (2016). Does environmental governance matter for FDI? Testing for pollution haven hypothesis for Indian states (No. 2016-54). Copenhagen Discussion Papers.

Kamran, M. (2018). Current status and future success of renewable energy in Pakistan. Renewable and Sustainable Energy Reviews, 82, 609-617.

Khan, M. A., Khan, J. A., Ali, Z., Ahmad, I., \& Ahmad, M. N. (2016). The challenge of climate change and policy response in Pakistan. Environmental Earth Sciences, 75(5), 412.

Khan, R., \& Chaudhry, I. S. (2019). Impact of human capital on employment and economic growth in developing countries. Review of Economics and Development Studies, 5(3), 487-496.

Le, M. H.,\&Ataullah, A. (2002). Foreign Capital and Economic Performance of Pakistan.The Lahore Journal of Economics, 7(1), 01-32.

Levinson, A. (1996). Environmental regulations and manufacturers' location choices: Evidence from the Census of Manufactures. Journal of public Economics, 62(1-2), 5-29.

Lee, C. C., \& Chang, C. P. (2007). The impact of energy consumption on economic growth: Evidence from linear and nonlinear models in Taiwan. Energy, 32(12), 2282-2294.

Lee, J. W. (2013). The contribution of foreign direct investment to clean energy use, carbon emissions and economic growth. Energy Policy, 55, 483-489.

Lindmark, M. (2002). An EKC-pattern in historical perspective: carbon dioxide emissions, technology, fuel prices and growth in Sweden 1870-1997. Ecological economics, 42(1- 2), 333-347.

Mahmood, H., \& Chaudhary, A. R. (2012). FDI, population density and carbon dioxide emissions: A case study of Pakistan. Iranica Journal of Energy \& Environment, 3(4), 354-360.

Maji, I. K., Habibullah, M. S., Saari, M. Y., \& Abdul-Rahim, A. S. (2017). The nexus between energy price changes and environmental quality in Malaysia. Energy Sources, Part B: Economics, Planning, and Policy, 12(10), 903-909.

Malik, M. Y., Latif, K., Khan, Z., Butt, H. D., Hussain, M., \& Nadeem, M. A. (2020). Symmetric and 
asymmetric impact of oil price, FDI and economic growth on carbon emission in Pakistan: Evidence from ARDL and non-linear ARDL approach. Science of The Total Environment, 138421.

McCollum, D. L., Jewell, J., Krey, V., Bazilian, M., Fay, M., \& Riahi, K. (2016). Quantifying uncertainties influencing the long-term impacts of oil prices on energy markets and carbon emissions. Nature Energy, 1(7), 1-8.

Nadeem, A. M., Ali, T., Khan, M. T., \& Guo, Z. (2020). Relationship between inward FDI and environmental degradation for Pakistan: an exploration of pollution haven hypothesis through ARDL approach. Environmental Science and Pollution Research, 1-19.

Najia, S., Maryam, M.,\& Rafique, N.(2013). Impact of Foreign Direct Investment on Economic Growth of Pakistan.Advances in Management and Applied Economics, 3(1), 35-45.

NTDC. (2017). Power System Statistics. Pakistan: National Transmission \& Despatch Company Retrieved from www.ntdc.som.pk

Ozturk, I. (2010). A literature survey on energy-growth nexus. Energy policy, 38(1), 340-349.

Payne, J. E. (2012). The causal dynamics between US renewable energy consumption, output, emissions, and oil prices. Energy Sources, Part B: Economics, Planning, and Policy, 7(4), 323-330.

Pao, H. T., \& Tsai, C. M. (2010). CO2 emissions, energy consumption and economic growth in BRIC countries. Energy policy, 38(12), 7850-7860.

Pesaran H, Shin Y (1999) An autoregressive distributed lag modeling approach to cointegration analysis. In: Strom S (ed) Econometrics and economic theory in 2oth century: the Ragnar-Frisch centennial symposium. Cambridge University Press, Cambridge.

Pesaran, M. H., Shin, Y., \& Smith, R. J. (2001). Bounds testing approaches to the analysis of level relationships. Journal of applied econometrics, 16(3), 289-326.

Presno, M. J., Landajo, M., \& González, P. F. (2017). Stochastic convergence in per capita CO2 emissions. An approach from nonlinear stationarity analysis. Energy Economics, 70, 563-581.

Rafique, M. M., \& Rehman, S. (2017). National energy scenario of Pakistan-Current status, future alternatives, and institutional infrastructure: An overview. Renewable and Sustainable Energy Reviews, 69, 156-167.

Raza, A., Iqbal, N., Ahmed, Z., Ahmed, M.,\& Ahmed, T. (2012). Role of FDI on Stock Market Development: The Case of Pakistan. Journal of Economics and Behavioral Studies, 4(1), 26-33.

Saboori, B., \& Sulaiman, J. (2013). CO2 emissions, energy consumption and economic growth in Association of Southeast Asian Nations (ASEAN) countries: A cointegration approach. Energy, 55, 813-822.

Sadorsky, P. (2009). Renewable energy consumption and income in emerging economies. Energy policy, 37(10), 4021-4028.

Safdar, N., Chaudhry, I. S., \& Chaudhry, M. O. (2019). Energy Consumption, Environmental Degradation and Economic Growth in Developing Countries. Pakistan Journal of Social Sciences (PJSS), 39(2).

Salim, R. A., \& Rafiq, S. (2012). Why do some emerging economies proactively accelerate the adoption of renewable energy?. Energy Economics, 34(4), 1051-1057.

Sarkodie, S. A., \& Strezov, V. (2019). Effect of foreign direct investments, economic development and energy consumption on greenhouse gas emissions in developing countries. Science of the Total Environment, 646, 862-871.

Sarwar, F., Fakher, A., Ali, S., \& Mudassar, K. (2013). Human capital, population and economic growth: A cointegration approach. Universal Journal Of Management And Social Sciences, 3(10), 20-32.

Sharif, A., \& Raza, S. A. (2016). Dynamic relationship between urbanization, energy consumption and environmental degradation in Pakistan: Evidence from structure break testing. Journal of Management Sciences, 3(1), 1-21. 
Shin, Y., Yu, B., \& Greenwood-Nimmo, M. (2014). Modelling asymmetric cointegration and dynamic multipliers in a nonlinear ARDL framework. In Festschrift in honor of Peter Schmidt (pp. 281314). Springer, New York, NY.

Stocker, T. F., Qin, D., Plattner, G. K., Tignor, M., Allen, S. K., Boschung, J., ... \& Midgley, P. $\quad$ M. (2013). Climate change 2013: The physical science basis. Contribution of working group I to the fifth assessment report of the intergovernmental panel on climate change, 1535.

Suleman, A. (2009). Fostering Foreign Direct Investment in Agriculture Sector. The Pakistan Development Review, 48(4- Part II), 821-838.

UN. (1992). International Earth Summit Paper presented at the International Earth Summit Brazil.

Usman, O., Olanipekun, I. O., Iorember, P. T., \& Abu-Goodman, M. (2020). Modelling environmental degradation in South Africa: the effects of energy consumption, democracy, and globalization using innovation accounting tests. Environmental Science and Pollution Research, 1-16.

Wang, Q., \& Li, R. (2016). Impact of cheaper oil on economic system and climate change: A SWOT analysis. Renewable and Sustainable Energy Reviews, 54, 925-931.

World Bank. (2018). World Bank Development Indicators. Retrieved from: https://data.worldbank.org/indicator/

Zaman, K., Shah, I.A., Khan, M.M.,\& Ahmad, M. (2012). Macroeconomic Factors Determining FDI Impact on Pakistan's Growth. South Asian Journal of Global Business Research, 1(1), 7995.

Zeng, K.,\& Eastin, J. (2012). Do Developing Countries Invest Up? The Environmental Effects of Foreign Direct Investment from Less-Developed Countries.World Development, 40(11), 2221-2233.

Zhang, J., \& Zhang, L. (2016). Impacts on CO2 emission allowance prices in China: A quantile regression analysis of the Shanghai emission trading scheme. Sustainability, 8(11), 1195.

\section{Appendix}

Table A1 Descriptive Statistics and Correlation

\begin{tabular}{|c|c|c|c|c|c|c|}
\hline & $\mathrm{CO} 2$ & OP & $\mathrm{GCF}$ & FDI & EC & POP \\
\hline Mean & 91.0723 & 1.5067 & 1.2472 & 22.9900 & 1.0529 & $1.34 \mathrm{E}+08$ \\
\hline Median & 85.8524 & 1.4591 & 1.2556 & 23.6173 & 1.0842 & $1.31 \mathrm{E}+08$ \\
\hline Maximum & 195.7069 & 2.0479 & 1.3184 & 29.7861 & 1.2487 & $2.12 \mathrm{E}+\mathrm{o} 8$ \\
\hline Minimum & 21.2233 & 1.1043 & 1.1498 & $15 \cdot 3055$ & 0.7546 & 68834326 \\
\hline Std. Dev. & 50.9607 & 0.2914 & 0.0404 & 3.8139 & 0.1402 & 43420937 \\
\hline Skewness & 0.2944 & 0.4522 & -0.6306 & -0.3679 & -0.5455 & 0.1711 \\
\hline Kurtosis & 1.9151 & 1.9942 & 2.5318 & 2.5075 & 2.1920 & 1.8000 \\
\hline Jarque-Bera & 2.7300 & 3.2781 & 3.2432 & 1.4048 & $3 \cdot 3025$ & 2.7896 \\
\hline Probability & 0.2554 & 0.1942 & 0.1976 & 0.4953 & 0.1918 & 0.2479 \\
\hline Sum & 0.2554 & 64.7889 & 53.6294 & 988.5710 & 45.2777 & $5.77 \mathrm{E}+09$ \\
\hline Sum Sq. Dev. & 3916.109 & 3.5670 & 0.0685 & 610.9137 & 0.8259 & $7 \cdot 92 \mathrm{E}+16$ \\
\hline $\mathrm{CO} 2$ & 1 & & & & & \\
\hline $\mathrm{OP}$ & 0.7367 & 1 & & & & \\
\hline GCF & -0.6067 & -0.5461 & 1 & & & \\
\hline FDI & -0.4032 & -0.4088 & 0.6703 & 1 & & \\
\hline EC & 0.9472 & 0.6452 & -0.4678 & -0.1931 & 1 & \\
\hline POP & 0.9937 & 0.7365 & -0.6476 & -0.4274 & 0.9528 & 1 \\
\hline
\end{tabular}

